\title{
SEMBLANZA ICONOGRÁFICA DE LA REALEZA SAPIENCIAL DE ALFONSO X: LAS MINIATURAS LIMINARES DE LOS CÓDICES REGIOS*
}

\author{
Marta Haro Cortés \\ Universitat de València \\ marta.haro@uv.es
}

La producción libraria de Alfonso X testimonia la simbiosis perfecta entre las funciones de gobierno y la creación literaria: el saber como principio rector del ejercicio del poder, del diseño de la corte, de la convivencia del reino y de la aprehensión del mundo, en suma, la instrumentalización de la sabiduría y del conocimiento para escribir su propia historia y con ella enarbolar la idea sapiencial de la realeza alfonsí con un claro fin propagandista de cara a la consecución de sus aspiraciones políticas ${ }^{1}$.

La «autoría intelectual» de Alfonso X, tanto en su producción personal como en su labor de mecenazgo, se proyecta con determinación e intencionadamente desde el proceso de composición textual de cada una de sus obras, hasta su materialización en un ejemplar de rica factura ${ }^{2}$. En esta última fase,

${ }^{*}$ Este trabajo se inscribe en el Proyecto de Investigación FFI2014-51781-P concedido por el Ministerio de Economía y Competitividad.

${ }^{1}$ Para la bibliografía sobre Alfonso X, su reinado y obras, remito a la sección correspondiente del portal Alfonso X el Sabio de la Biblioteca Virtual Miguel de Cervantes, a cargo de Francisco Bautista. Enlace: <http://www.cervantesvirtual.com/portales/alfonso_x_el_sabio/> [Consulta: 30/01/2016]; R. J. González-Casanovas, «Alfonso X Studies 1983-1994: General Bibliography with Analytical Tables», en Exemplaria Hispanica, 3 (1993-1994), pp. 1-139 y al Boletín Bibliográfico de la Asociación Hispánica de Literatura Medieval. [En línea]. Enlace: <http://www.ahlm.es/Boletin.htm> [Consulta: 30/01/2016].

${ }^{2}$ Pueden consultarse a este respecto los clásicos estudios de Gonzalo Menéndez Pidal, «Como trabajaron las escuelas alfonsíes», en Nueva Revista de Filología Hispánica, 5 (1951), pp. 363-380; A. García Solalinde, «Intervención de Alfonso X en la redacción de sus obras», en Revista de Filología Española, 2 (1915), pp. 284-286; María Rosa Lida, «La General Estoria: notas literarias y filológicas», en Romance Philology, 12 (1958-59), pp. 1-30; Fernando Lázaro Carreter, «Sobre el modus operandi de Alfonso X», en Ibérida, 6 (1961), pp. 97-114; Diego Catalán, «El taller historiográfico alfonsí. Métodos y problemas en el trabajo compilatorio», en Romania, 84 (1963), pp. 354-375; Francisco Rico, Alfonso el Sabio y la General Estoria, Barcelona, Ariel, 1973 y Francisco Márquez Villanueva, El concepto cultural alfonsí, 
la voz del rey y su ambición cultural se vierten en páginas, que estructuran jerárquicamente el contenido -en libros, títulos y capítulos-, y que son artísticamente diseñadas - cabeceras, iniciales decoradas de diversos tamaños, títulos rubricados- e ilustradas con un exquisito aparato icónico -para intensificar la asimilación y comprensión de la materia-. La escritura integra la labor intelectual y de gobierno de Alfonso X y el libro sistematiza su ideario político y cultural y su propia semblanza como rey letrado, no solo en texto, sino también en imagen ${ }^{3}$.

Si bien es innegable la calidad y originalidad artística de las ilustraciones alfonsíes y la complejidad que reviste su filiación estilística ${ }^{4}$, no menos rele-

edición revisada y aumentada, Barcelona, Ediciones Bellaterrra, 2004. Véanse también, Francisco Javier Díez de Revenga, «Alfonso X y su condición de autor literario: la General estoria», en La lengua y la literatura en tiempos de Alfonso X, ed. de Fernando Carmona y Francisco J. Flores, Murcia, Universidad de Murcia, 1985, pp. 159-167 y «La condición de autor literario en Alfonso X el Sabio: Crónica General», en Miscelánea Medieval Murciana, 13 (1986), pp. 118-129; Jesús Montoya Martínez, «El concepto de "autor" en Alfonso X», en Estudios sobre literatura y arte: dedicados al profesor Emilio Orozco Díaz, 3 vols., coord. por Nicolás Marín, Antonio Gallego Morell y Andrés Soria Olmedo, Granada, Universidad de Granada, 1979, II, pp. 455-462.

${ }^{3}$ Alfonso X encarna el modelo de rex scribens: «Alfonso X de Castilla ha sido de entre los representantes peninsulares de una Corona quien mejor ha comprendido el valor de la escritura y la necesidad de su utilización para dar a conocer el propio ideario político y ponerlo en práctica», remito al excelente trabajo de Elisa Ruiz García, «Rex scribens: discursos de la conflictividad en Castilla (1230-1350)», en La monarquía como conflicto en la Corona castellano-leonesa (c. 1230-1504), dir. José Manuel Nieto Soria, Madrid, Sílex, 2006, pp. 359-422, cita p. 361. La Cancillería como espacio político y cultural, Francisco Ruiz Gómez, «Los espacios políticos de la cultura. Los modelos culturales de la monarquía castellana bajomedieval: la Cancillería», en Modelos culturales y normas sociales al final de la Edad Media, coord. por Patrick Boucheron y Francisco Ruiz Gómez, Cuenca, Casa de Velázquez - Ediciones Universidad de Castilla-La Mancha, 2009, pp. 113-134. Por lo que se refiere al sobrenombre sapiencial de Alfonso X, véanse principalmente: Adeline Rucquoi, «El rey sabio: cultura y poder en la monarquía medieval castellana», en Actas del III Curso de Cultura Medieval. Seminario: repoblación y reconquista, Aguilar de Campoo, Centro de Estudios del Románico, 1993, pp. 77-87; Daniel Gregorio, «Alfonso X de Castilla, o la sabiduría como herramienta de poder», en De Arte, 7 (2008), pp. 61-76 y Manuel Alejandro Rodríguez de la Peña, «Rex excelsus qui scientiam diliget: la dimensión sapiencial de la Realeza alfonsí», en Alcanate, IX (2014-2015), pp. 107-135.

${ }^{4}$ Sería interminable ofrecer referencia completa de todos los estudios que se ocupan de la miniatura alfonsí y de su importancia en la historia del arte medieval, véanse las bibliografías de Carlos Miranda García, «Bibliografía sobre miniatura alfonsí e historia del arte», en Alcanate, I (1998-1999), pp. 308-314 y Ana Domínguez Rodríguez, «Bibliografía de la miniatura alfonsí», en Alcanate, III (2002-2003), pp. 311-318. Por lo que respecta a la filiación y fuentes de las miniaturas alfonsíes, remito principalmente a los clásicos trabajos de Rafael Cómez Ramos, Las empresas artísticas de Alfonso X el Sabio, Sevilla, Diputación Provincial, 1979 y «Tradición e innovación artísticas en Castilla en el siglo xIII», en Alcanate, III (2002-2003), pp. 135-163; Joaquín Yarza, Baja Edad Media. Los siglos del gótico, Madrid, Sílex, 1992; J. Guerrero Lovillo, Miniatura gótica castellana. Siglos XIII y XIV, Madrid, CSIC, 1956. Y a las aportaciones de Ana Domínguez Rodríguez, «Filiación estilística de la miniatura alfonsí», en Actas del XXIII Congreso Internacional de Historia del Arte. España entre el Mediterráneo y el Atlántico (Granada, 1973), Granada, Universidad de Granada, Departamento de Historia del Arte, 1976, I, pp. 345-358; «La miniatura del "scriptorium" alfonsí», en Estudios alfonsies. Lexicografía, lírica, estética y política de Alfonso X el Sabio, ed. de José Mondéjar y Jesús Montoya, Granada, Facultad de Filosofía y Letras - Instituto de 
vante es la cronología de la elaboración material de los ejemplares del taller alfonsí y, por tanto, de su repertorio figurativo - punto de partida del presente trabajo- para delinear la evolución del modelo iconográfico de realeza sapiencial que Alfonso X consolida en las exquisitas miniaturas liminares de sus códices regios.

Los ejemplares del scriptorium alfonsí con imágenes del rey -como se sintetiza en la tabla que sigue- fueron realizados en la última década de su reinado ${ }^{5}$. Hecho este que está íntimamente ligado a la continua revisión y reelaboración de sus obras y que responde tanto a su talante perfeccionista y enciclopédico, como, a mi entender, en mayor medida, a la propia trayectoria, conflictos y crisis que jalonaron su reinado ${ }^{6}$.

Ciencias de la Educación, 1985, pp. 127-161; La miniatura en la Corte de Alfonso X, Cuadernos de Arte Español, 35, Madrid, Historia 16, 1991 y «Sevilla y el "scriptorium" alfonsí», en Sevilla 1248. Congreso Internacional Conmemorativo del 750 aniversario de la conquista de Sevilla por Fernando III el Santo, rey de Castilla y León, coord. por M. González Giménez, Sevilla - Madrid, Ayuntamiento de SevillaFundación Ramón Areces, 2000, pp. 635-659. Un completo estado de la cuestión en Rocío Sánchez Ameijeiras, «Del Salterio al Marial: sobre las ‘fuentes' de las imágenes de los Códices de las Historias de las Cantigas de Santa María», en Alcanate, VIII (2012-2013), pp. 55-80, principalmente, pp. 55-61. Por lo que se refiere a otras representaciones de Alfonso X, recomiendo la consulta de Fátima Pavón Casar, $L a$ imagen de la realeza castellana bajomedieval en los documentos y manuscritos, Tesis Doctoral, Madrid, Universidad Complutense, 2009, especialmente, pp. 88-205. Todas las imágenes que aparecen en este trabajo proceden de los facsímiles de las obras de Alfonso X que se irán citando a lo largo del artículo; asimismo, en cada ilustración se indica el manuscrito de procedencia.

${ }^{5}$ Seguimos la cronología resultante del estudio codicológico de los códices alfonsíes propuesta por Laura Fernández Fernández, «Transmisión del Saber - Transmisión del Poder. La imagen de Alfonso X en la Estoria de España, Ms, Y-I-2, RBME», en Anales de Historia del Arte, Volumen extraordinario (2010), pp. 187-210; «Los manuscritos de las Cantigas de Santa María: definición material de un proyecto regio», en Alcanate, VIII (2012-2013), pp. 81-117 y Arte y ciencia en el scriptorium de Alfonso X el Sabio, Puerto de Santa María - Sevilla, Cátedra Alfonso X el Sabio - Universidad de Sevilla, 2013. Puede verse también, María Victoria Chico Picaza, «Cronología de la miniatura alfonsí: estado de la cuestión», en Anales de la Historia del Arte. Homenaje al Profesor Dr. D. José María de Azcárate, 4 (1994), pp. 569-576 y Ana Domínguez Rodríguez, «Texto, imagen y diseño de la página en los códices de Alfonso X el Sabio (1252-1284)», en Imágenes y promotores en el arte medieval. Miscelánea en homenaje a Joaquín Yarza Luaces, ed. de M. ${ }^{a}$ Luisa Melero Moneo, Francesca Español Bertrán, Anna Orriols i Alsina y Daniel Rico, Bellaterra, Universitat Autònoma de Barcelona, 2001, pp. 313-326.

${ }^{6}$ La mayoría de historiadores del arte, siguiendo las propuestas de Ana Domínguez Rodríguez, reiteran que los «retratos de autor» de Alfonso X -que la estudiosa clasifica en escenas de presentación o dedicación, imágenes del rey trovador y episodios y aficiones del monarca- son tanto la constatación de su sabiduría, como un eslabón más de su escalada propagandista al trono imperial. Remito principalmente a Ana Domínguez Rodríguez, «Imágenes de presentación de la miniatura alfonsí», en Goya, 131 (1976), pp. 287-291; «Poder, ciencia y religión en la miniatura de Alfonso X el Sabio. Una aproximación», en Fragmentos, 2 (1984), pp. 34-46; «Retratos de Alfonso X en sus manuscritos», en Alfonso X el Sabio impulsor del arte, la cultura y el humanismo. El arpa en la Edad Media española, Madrid, Asociación Arpista Ludovico, 1997, pp. 95-107. Véanse también los artículos de esta estudiosa citados en notas 4 y 5. 


\begin{tabular}{|c|c|c|}
\hline OBRA & FECHA CÓDICE & IMÁGENES DE ALFONSO X \\
\hline $\begin{array}{l}\text { Lapidario } \\
\text { BE, h.I.15 }\end{array}$ & ca. $1275-1276$ & $\begin{array}{l}\text { Imagen liminar de apertura-capital historiada } \\
\text { Prólogo, f. 1r. }\end{array}$ \\
\hline $\begin{array}{l}\text { Libro de las formas e imágenes } \\
\text { BE, h.I.6 }\end{array}$ & ca. $1276-1279$ & $\begin{array}{c}\text { Imagen liminar de apertura-capital historiada } \\
\text { Prólogo, f.1r. }\end{array}$ \\
\hline $\begin{array}{c}\text { Estoria de España } \\
\text { BE, ms. Y.I.2 } \\
\text { [+ ff. 1-17, BE, ms. X.I.4] }\end{array}$ & $\begin{array}{l}\text { ca. } 1270 \text { y antes } 1274 \\
\text { f. } 1, \text { ca. } 1281\end{array}$ & $\begin{array}{l}\text { Imagen liminar de apertura, } \mathrm{f} .1 \mathrm{v} \\
\text { [añadido posteriormente] }\end{array}$ \\
\hline $\begin{array}{l}\text { General Estoria, IV Parte } \\
\text { Roma, Biblioteca Apostólica } \\
\text { Vaticana, ms. Urb. Lat } 539\end{array}$ & 1280 & Imagen liminar de apertura, f. $2 \mathrm{v}$. \\
\hline $\begin{array}{l}\text { Cantigas de Santa María } \\
\text { Códice Rico, BE, T.I.1 }\end{array}$ & Iniciado ca. 1280 & $\begin{array}{l}\text { Imágenes liminares de apertura } \\
\text { Prólogo, f. 4v. } \\
\text { Intitulación, f. 5r. }\end{array}$ \\
\hline $\begin{array}{c}\text { Cantigas de Santa María } \\
\text { Códice de Florencia, } \\
\text { Biblioteca Nazionale Centrale } \\
\text { di Firenze, ms. B.R.20 }\end{array}$ & ca. $1282-1284$ & $\begin{array}{l}\text { Imagen liminar de apertura } \\
\text { Cantiga loor (f. } 2 \text { r [IIIr]). }\end{array}$ \\
\hline $\begin{array}{c}\text { Cantigas de Santa María } \\
\text { Códice de los Músicos, BE, b.I.2 }\end{array}$ & ca. $1282-1284$ & Imagen liminar de apertura, f. 29r. \\
\hline $\begin{array}{c}\text { Libro del ajedrez, dados y tablas } \\
\text { BE, T.I.6 }\end{array}$ & 1283 & $\begin{array}{l}\text { Imagen liminar apertura, f. } 1 \mathrm{r} \\
\text { (Libro del ajedrez). } \\
\text { Imagen liminar apertura, f. } 65 \mathrm{r} \\
\text { (Libro de los dados). } \\
\text { Imagen liminar apertura, f. } 72 \mathrm{r} \\
\text { (Libro de las tablas). }\end{array}$ \\
\hline $\begin{array}{c}\text { Primera Partida* } \\
\text { Londres, British Library, } \\
\text { Add. ms. } 20787\end{array}$ & Posterior a Alfonso X & No será tratado en este estudio. \\
\hline
\end{tabular}

\section{Las compilaciones científicas: imágenes proemiales}

El Primer Lapidario (ff. 1r-93v) se tradujo hacia 1243-1250, pero será aproximadamente entre 1275-1276 cuando se compendien los cuatro lapidarios, se redacte el prólogo y se lleve a cabo el códice regio (BE, h.I.15)7. Esta revisión del Lapidario estaría vinculada a la realización del ejemplar del

${ }^{7}$ El prólogo del Lapidario es de enorme interés para trazar la historia de la transmisión de la obra y el proceso de traducción de la misma. Las fechas aportadas «son aplicables con seguridad al primero de los cuatro lapidarios que se encuentran en el manuscrito, quedando fuera de este marco cronológico tan definido, y del proceso de transmisión establecido, los tres lapidarios restantes, sin poder afirmar si ellos también formaban parte de ese códice que se encontraba en manos del judío toledano, y si fueron los mismos traductores: Yehudá y Garcí Pérez los que intervinieron en los cuatro lapidarios», Laura Fernández Fernández, Arte y ciencia en el scriptorium de Alfonso X el Sabio, ob. cit., pp. 135-211, cita p. 143. La relevancia y análisis del aparato icónico del Lapidario en ibídem, pp. 161-97; también Ana Domínguez Rodríguez, Astrología y arte en El Lapidario de Alfonso X el Sabio, Madrid, Real Academia Alfonso X el Sabio, 2006 y María Victoria Chico Picaza, «La decoración marginal en el Lapidario de Alfonso X el Sabio (Escorial, ms. h.1.15)», en Reales Sitos, 151:1 (2002), pp. 2-13. 
Libro de las formas e imágenes (BE, h.I.6) -ya que tanto esta como el primer tratado del Lapidario comparten materia, fuente y la mención del sabio Abolays-, obra que, según reza en el prólogo, se comenzó en 1276 y se concluyó en $1279^{8}$.

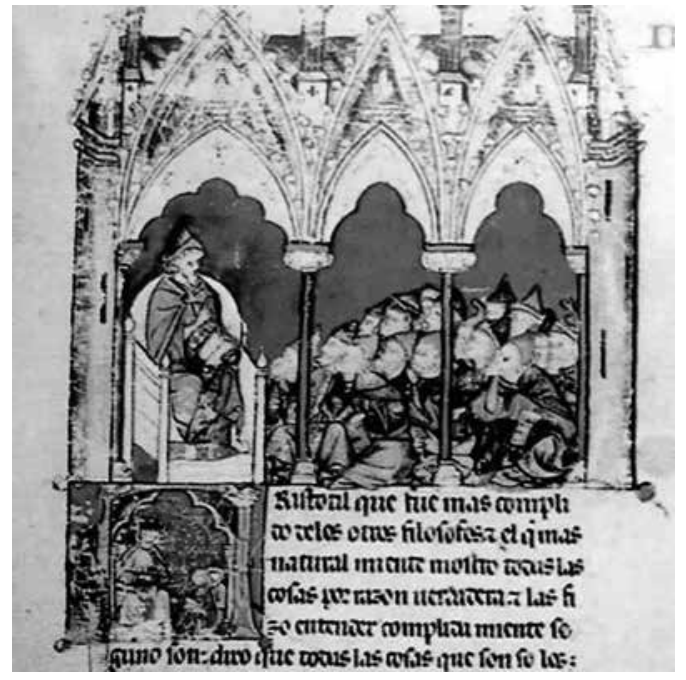

Lapidario, BE, ms. h.I.15, f. 1 r.

La miniatura que inaugura el Lapidario (f. 1r) y la viñeta que se halla en el cuerpo de la primera capital (f. 1r) forman una secuencia que concreta los dos puntos principales del peregrinaje textual de la obra.

En primer lugar, Aristóteles, ejerciendo su magisterio desde la cátedra, es la auctoritas que avala el contenido y origen del texto. Esta miniatura sigue muy de cerca la representación iluminada del filósofo que se explicita al comienzo del Libro de los buenos proverbios -obra de sobra conocida en el entorno alfonsí-: «E en el comienço del libro avié figura del philóphoso iluminado et assentado en su siella et las figuras de los descípulos antél deprendiendo lo que dizié»» ${ }^{9}$. La siguiente ilustración, de menor

\footnotetext{
${ }^{8}$ Remito a Alejandro García Avilés, «Two Astromagical Manuscripts of Alfonso X», en Journal of the Warburg and Courtauld Institutes, 59 (1996), pp. 14-23; "Alfonso X y la tradición de la magia astral», en Scriptorium alfonsí, de los libros de astrología a las Cantigas, coord. por A. Domínguez Rodríguez y J. Montoya Martínez, Madrid, Universidad Complutense, 1999, pp. 83-104 y El tiempo y los astros. Arte, ciencia y religión en la Alta Edad Media, Murcia, Universidad de Murcia, 2000; «La cultura visual de la magia en la época de Alfonso X», en Alcanate, V (2006-2007), pp. 49-87; también Ana Domínguez Rodríguez, Astrología y arte en El Lapidario de Alfonso X el Sabio, ob. cit., pp. 281-88. Para la relación entre el Lapidario y el Libro de las formas e imágenes, además de los estudios antes citados, Alejandro García Avilés, «Alfonso X y el Liber Razielis: imágenes de la magia astral judía en el scriptorium alfonsí», en Bulletin of Hispanic Studies, 74 (1997), pp. 21-39; «Imagen y ritual: Alfonso X y la creación de imágenes en la Edad Media», en Anales de Historia del Arte, número extr. (2010), pp. 11-29; Ana Domínguez Rodríguez, "Originales astrológicos de Alfonso X, el Sabio y copias del siglo XVI (Lapidario y Libro de las figuras de las estrellas fijas). Uno de sus modelos», en Vè Congrés Espanyol d'Historia de l'Art, ed. de Joaquin Yarza y Francesca Espanyol, 2 vols., Barcelona, Departament de Cultura de la Generalitat de Catalunya, 1987-1988, I, pp. 39-47 y «Astrología y mitología en los manuscritos ilustrados de Alfonso X E1 Sabio», en En la España Medieval, 30 (2007), pp. 27-64.

${ }^{9}$ Libro de los buenos proverbios, ed. de Christy Bandak, Zaragoza, Instituto de Estudios Islámicos y del Oriente Próximo, 2006, p. 6. Fue Ana Domínguez Rodríguez, Astrología y Arte en el Lapidario de Alfonso X, ob. cit., pp. 10-11, quien basándose en el Libro de los buenos proverbios fijó que era Aristóteles el maestro representado en la miniatura.
} 
tamaño pero de marcada simbología, enlaza por medio de la mayúscula historiada, que no en balde inicia el texto y es una A, la figura del Filósofo y la de Alfonso X, que se presenta en su escaño atendiendo a los dos colaboradores que tiene ante él; uno de ellos, el más próximo al soberano, porta un libro abierto en sus manos.

A tenor de la información proporcionada en el proemio:

Mas los que escrivieron de las piedras, así como Aristótil, que fizo un libro en que nombró sietecientas d'ellas [...]. Y después que él murió [Abolais] fincó como perdudo este libro muy grand tiempo [...], fasta que quiso Dios que viniesse a manos del noble rey don Alfonso [...]. Y ovol en Toledo de un judío qu'el tenié ascondido que se non querié aprovechar d'él, nin que a otro tuviesse pro. Y desque este libro tovo en su poder [Alfonso X], fízolo leer a otro su judío que era su físico y dizíenle Yhuda Mosca, el menor, [... y sabié y entendié bien el arávigo y el latín. Y desque por este judío, su físico, ovo entendido el bien y la grand pro que en él yazié, mandó gelo trasladar de arávigo en lenguaje castellano [...]. Y ayudole en este trasladamiento Garci Pérez, un su clérigo, que era otrossí mucho entendudo en este saber de astronomía (BE, h.I.15, f. 1r-v).

Considero que no se trata de una escena de presentación del ejemplar terminado a su comitente, sino que más bien estamos ante la estampa del proceso de traducción, detallado en el prólogo, y que constituye la última fase, la alfonsí, de la transmisión de la obra ${ }^{10}$.

$\mathrm{Al}$ igual que en el Lapidario, en el Libro de las formas e imágenes (BE, ms. h.I.16) -compilación científica de diversos tratados sobre las propiedades de las piedras «que mandó componer de los libros de los filósofos antiguos el mucho alto y onrado don Alfonso, amador de siencias y de saberes» (f. 1r)-, el rey aparece miniado en una capital $(\mathrm{P})$ y en el vástago de la misma están pintados castillos y leones a modo de cinta ${ }^{11}$.

\footnotetext{
${ }^{10}$ Ana Domínguez Rodríguez, Astrología y arte en El Lapidario de Alfonso X el Sabio, ob. cit., p. 11 , véanse también los trabajos citados en nota 7 , considera esta miniatura una escena de presentación del libro por parte de Yehudá Mosca y del clérigo Garci Pérez a Alfonso X, y la describe detalladamente; Laura Fernández Fernández, Arte y ciencia en el scriptorium de Alfonso X el Sabio, ob. cit., pp. 163-170, especialmente p. 168, opina que la imagen de la capital no es una escena de presentación, «sino de una acción de copia que está siendo ordenada por el rey [...] tal vez a la espera de la recepción del libro».

${ }^{11}$ «Junto a dichos motivos, en la parte superior del astil de la letra, se aprecian dos pequeños medallones, uno con una figura dotada de escudo y lanza, y otro con un ángel que con su índice señala al rey. Ambas figuras recuerdan en su estilo y definición a las iniciales y drôleries del Lapidario. En la parte inferior aún se aprecian las cabezas de dos dragones entrelazadas, también muy deterioradas. [...] Gracias al rostro de uno de los personajes arrodillados frente al rey con una fisonomía peculiar, podemos identificar fácilmente el iluminador que ha llevado a cabo esta imagen con uno de los maestros que participan en el Lapidario», Laura Fernández Fernández, Arte y ciencia en el scriptorium de Alfonso X el Sabio, ob. cit., pp. 286-287.
} 


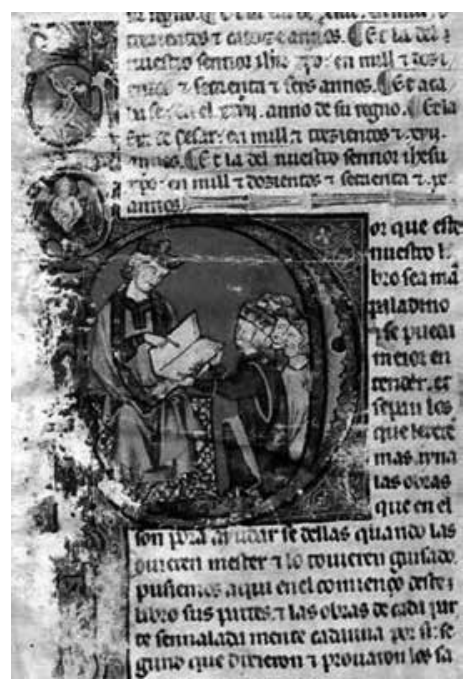

Libro de las formas y las imágenes, BE, ms. h.I.16, f. 1r.

No puede pasarse por alto que la escena se halla en la mayúscula que principia la declaración de intenciones del rey, inicial que, asimismo, marca en el texto y figurativamente resalta y enfatiza el paso de la tercera persona a la voz del rey -primera del plural-. El monarca con el códice en la mano y asistido por sus colaboradores señala claramente, con el dedo índice inhiesto, una página del libro. Aunque se ha considerado habitualmente una imagen de presentación del ejemplar a su promotor, a mi juicio -como en el Lapidario-, responde a un claro ejercicio de relación texto-imagen: «Por que este nuestro libro sea más paladino y se pueda mejor entender y sepan los que leyeren más aína las obras que en él son pora ayudarse d'ellas [...] pusiemos aquí en el comienço d'este libro sus partes y las obras de cada parte» (f. 1r). La miniatura ilustra las propias palabras del rey: es esa tabla general, sumario de las materias reunidas y síntesis desglosada del contenido, lo que está mostrando Alfonso X en el ejemplar abierto que sostiene y que, en definitiva, más allá de la acción concreta, alude y representa su labor de patronazgo compilador de los saberes de la ciencia, que artísticamente es reforzado con los emblemas heráldicos y adquiere tintes salomónicos con el medallón del ángel que señala al soberano.

Los códices científicos que incluyen la imagen del rey se llevaron a cabo a partir de 1275 y todos ellos son fruto de la intensa labor de compilación y revisión que el scriptorium alfonsí emprendió una vez frustrado el sueño del imperio. En el Lapidario (1275-1276) y en el Libro de las formas e imágenes (terminado en 1279), Alfonso X aparece en el cuerpo de una capital. Y es muy probable que también hubiese sido representado de forma muy similar en la inicial historiada -que ha sido mutilada- del Libro del saber de astrología (ejemplar realizado en Burgos, en 1278), así como en el Libro de astromagia (realizado ca. 1280-1281) -que no conserva los primeros folios pero sí presenta repertorio figurativo- ${ }^{12}$. Nótese, además, que frente a la tercera persona

${ }^{12}$ Libro del saber de astrología, Madrid, Biblioteca Histórica Marqués de Valdecilla, Universidad Complutense, ms. 156; ejemplar digitalizado. [En línea]. Enlace: $<$ http://alfama.sim.ucm.es/dioscorides/ consulta_libro.asp?ref=B18550071\&idioma $=0>$ [Consulta: 06/02/2016]; Libro de astromagia, Roma, Biblioteca Āpostólica Vaticana, ms. Reg. Lat. 1283a. Ed. de Alfonso D’Agostino, Astromagia (Ms. Reg. Lat. 
que preside el prólogo del Lapidario - que se redactaría al llevarse a cabo la revisión de la obra, pero que incluiría los datos de la primera versión (traducción realizada entre 1243 y 1250)-, en los preliminares del Libro del saber de astrología, del Libro de las formas e imágenes y del Libro de astromagia, Alfonso X evidencia su presencia y su labor en primera persona ${ }^{13}$. Si bien el rey tuvo notoria predilección por «figurar» la ciencia «porque los que esto quisiessen aprender lo podiessen más de ligero saber, non tan solamientre por entendimiento mas aun por vista» (Prólogo del Libro del saber de astrología, Biblioteca Histórica Marqués de Valdecilla, ms. 156, f. 1r), tamaño interés revela por «figurar» el contenido de los prólogos regios y, en definitiva, su implicación en dichas colecciones con su propia imagen. Las ilustraciones de las obras científicas, más que de presentación del códice terminado a su comitente, son miniaturas proemiales que concretan el mecenazgo traductor y compilador del monarca y, a mi entender, dan cuenta del primer eslabón de la representación de rex scribens de Alfonso X.

\section{Las Estorias: imágenes de legitimación y transmisión del poder}

La redacción de las Estorias se inició hacia 1270 y, procedentes del scriptorium alfonsí, conservamos el códice escurialense Y.I.2 de la Estoria de

1283a), Napoles, Liguori, 1992. Remito a Laura Fernández Fernández, Arte y ciencia en el scriptorium de Alfonso X el Sabio, ob. cit., respectivamente, pp. 213-279 y pp. 289-323. Respecto a la Compilación tabular del Arsenal (códice realizado hacia 1280-1281), París, Biblioteca del Arsenal, ms. 8322, este ejemplar no posee imágenes «no obstante, si aplicásemos la tendencia iconográfica observada en los textos científicos, podríamos plantear que en origen contase con una escena de presentación ubicada en la inicial de apertura del texto», Laura Fernández Fernández, ibídem, p. 332.

${ }^{13}$ Sobre los prólogos de Alfonso X, Rafael Cano Aguilar, «Los prólogos alfonsíes», en Cahiers de Linguistique Hispanique Médiévale, 14-15 (1989-1990), pp. 79-90; A. J. Cardenas, «The Literary Prologue of Alfonso X: a Nexus between Chancery and Scriptorium», en Thought, 60:239 (1985), pp. 456467, «Alfonso's Scriptorium and Chancery: Role of the Prologue in Bonding the Translatio Studii to the Translatio Potestatis», en Emperor of Culture. Alfonso X the Learned of Castile and his Thirteenth-Century Renaissance, ed. de R. Burns, Philadelphia, University of Pensilvania Press, 1990, pp. 90-108; Inés Fernández Ordóñez, «El taller historiográfico alfonsí», en Scriptorium alfonsí, de los libros de astrología a las Cantigas, coord. por A. Domínguez Rodríguez y J. Montoya Martínez, Madrid, Universidad Complutense, 1999, pp. 105-126; Roberto J. González-Casanova, «Alfonso X’s Rhetoric of Humanist Education: Professional Literacy in the Scientific Prologues», en Romance Languages Annual, 2 (1990), pp. 431-441 y «Book Culture in Alfonso X's Prologues: the Texts and Contexts of Wisdom», en Hispanofila, 111 (1994), pp. 1-15; K. Kennedy, «The Sabio-Topos: Prologues of Alfonso X in the Context of his Thirteenth-Century Royal Contemporaries», en Proceedings of the Ninth Colloquium, ed. de A. M. Beresford y A. D. Deyermond, London, Queen Mary and Westfield College, 2000, pp. 175-190; Marta Lacomba, «Les prologues scientifiques alphonsins et la symbolique du miroir», en Le Miroir du Prince. Écriture, transmission et réception en Espagne (XIII ${ }^{e}-X^{e} I^{e}$ siècles), ed. de G. Founès y E. Canonica, Bordeaux, Presses Universitaires de Bordeaux, 2011, pp. 113-129; George Martin, «Alphonse X ou la science politique. Septénaire 1-11», en Cahiers de linguistique hispanique médiévale, 18-19 (1993-1994), pp. 79100; Laura Fernández Fernández, Arte y ciencia en el scriptorium de Alfonso X el Sabio, ob. cit., pp. 42-50. 
España (versión primitiva) que se realizó aproximadamente entre 1270 y antes de 1274 -los dos últimos cuadernos, en total 17 folios, fueron desgajados y se incorporaron al manuscrito X.I.4-. Y la cuarta parte de la General Estoria, datada en 1280 (Roma, Biblioteca Apostólica Vaticana, ms. Urb. Lat. 549) ${ }^{14}$.

El repertorio icónico del ejemplar de la Estoria de España alcanza únicamente los siete primeros folios, quedando los espacios en blanco para ilustraciones e iniciales decoradas ${ }^{15}$. Los dos primeros folios, con la imagen de apertura (f. 1v) y el prólogo (f. 2), fueron añadidos posteriormente. La miniatura liminar es de cronología tardía, pudiéndose fechar en torno a $1280^{16}$. Por otro lado, en lo relativo a la IV Parte de la General Estoria, uno de sus artistas también trabajó en en Códice Rico de las Cantigas y además, «presenta relación directa con E [Códice de los Músicos], a través de la imagen de apertura de ambos ejemplares $\rangle^{17}$. Por tanto, parece factible suponer que en las mismas fechas los equipos alfonsíes estaban trabajando simultáneamente en el códice de la General Estoria y en los de las Cantigas.

\footnotetext{
${ }^{14}$ Remito principalmente a Inés Fernández-Ordóñez, Las Estorias de Alfonso el Sabio, Madrid, Istmo, 1992; Diego Catalán, De la silva textual al taller historiográfico alfonsí. Códices, crónicas, versiones y cuadernos de trabajo, Madrid, Fundación Ramón Menéndez Pidal, 1997; Leonardo Funes, El modelo historiográfico alfonsí: una caracterización, London, Department of Hispanic Studies - Queen Mary and Westfield College, 1997; Fernando Gómez Redondo, Historia de la prosa medieval castellana. I. La creación del discurso prosístico: el entramado cortesano, Madrid, Cátedra, 1998, pp. 643-796.

${ }^{15}$ Las cinco miniaturas son las siguientes: Arca de Noé (f. 3r), Hércules estrangulando dos leones (f. 4r), Faro de Hércules (f. 4v), portada con los seis pilares de la fundación de Sevilla por Hércules (f. 5r) y rey Rocas en la cueva de Toledo (f. 7v). Estas ilustraciones han sido estudiadas por Ana Domínguez Rodríguez, «Miniaturas alfonsíes poco conocidas de un códice escurialense: la Estoria de España o Primera Crónica General de España (Ms. Y.I.2 de la Biblioteca de El Escorial)», en I Jornadas de estudio sobre la provincia de Madrid (diciembre, 1979), Madrid, Instituto de España, 1980, pp. 159-164 y «Hércules en la miniatura de Alfonso X el Sabio», en Cuadernos de Arte e Iconografía, II:3 (1989), pp. 73-80 y en Anales de Historia del Arte 1 (1989), pp. 91-101. Puede verse también, Rosa María Rodríguez Porto, «De tradiciones y traiciones: Alfonso X en los libros iluminados para los reyes de Castilla (1284-1369», en El texto infinito. Tradición y reescritura en la Edad Media y el Renacimiento, ed. de Cesc Esteve, Salamanca, Seminario de Estudios Medievales y Renacentistas, Sociedad de Estudios Medievales y Renacentistas, 2014, pp. 947-962.

${ }^{16}$ Laura Fernández Fernández, «Transmisión del Saber - Transmisión del Poder. La imagen de Alfonso X en la Estoria de España, Ms. Y-I-2 RBME», art.cit. p. 204, expone sobre la ilustración inicial: «La complejidad compositiva y la técnica pictórica empleada nos sitúa en una fase muy desarrollada de la producción alfonsí, apareciendo detalles que nos remiten a otras obras del taller regio, como la mencionada escena de apertura de la IV parte de la General Estoria [...]. También encontramos puntos comunes con el Códice de los Músicos [...], en el que vemos un planteamiento muy similar en los fondos decorativos, y cuya producción también debemos situar en los años finales del reinado. Pero en lo que respecta a la aplicación del color, el canon de las figuras y ciertos rasgos físicos, debemos ponerla en relación con el iluminador del Libro de los juegos [...], fechado en 1283. [...]. Por tanto, la imagen podemos situarla en una cronología tardía, hacia 1280». La estudiosa lleva a cabo un detallado análisis de las miniaturas de las obras historiográficas, pp. 199-204.

${ }^{17}$ Laura Fernández Fernández, «Los manuscritos de las Cantigas de Santa María: definición material de un proyecto regio», art. cit., p. 112, n. 88.
} 


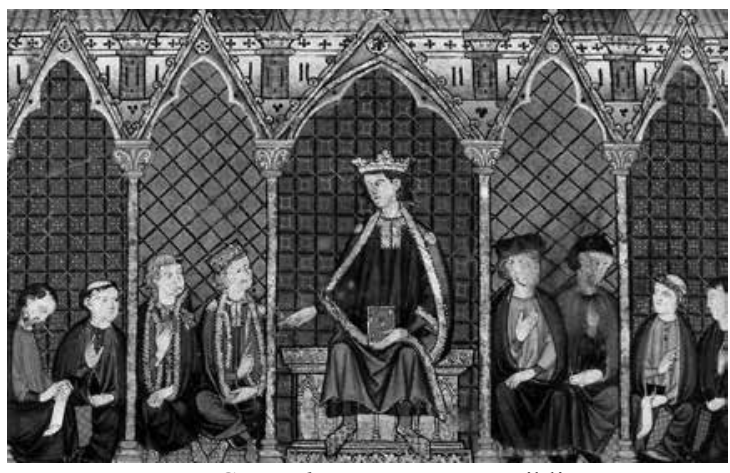

IV Parte General Estoria, Roma, Biblioteca Apostólica Vaticana, ms. Urb. Lat. 549, f. 2 v.

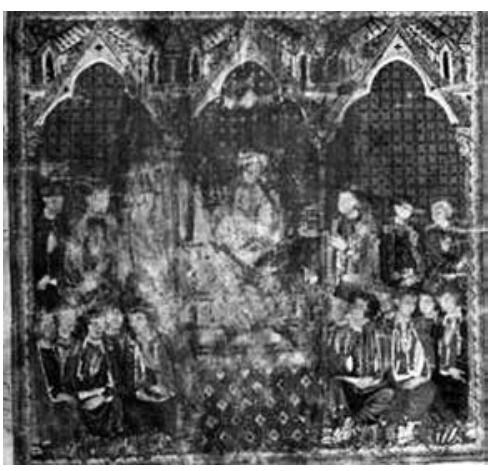

Estoria de España, Madrid, Biblioteca de El Escorial, ms. Y.I.2, f. 1v.

La escena de corte que se estampa en ambas miniaturas sigue un planteamiento similar: el rey sentado en su escaño ocupa el centro -lugar privilegiado- de la imagen y está rodeado por dos grupos de cortesanos. Sin embargo, las diferencias requieren especial atención: en la General Estoria, el rey apoya en su regazo un códice y está dirigiéndose al infante (parte izquierda) que luce el bonete recamado en oro; junto a ellos (extremo izquierdo) un clérigo y un laico parece que transcriben el discurso del monarca a su heredero -uno de ellos exhibe un rótulo en la mano y entre las piernas se distingue una especie de cartapacio-. A la derecha de la imagen, dos clérigos con bonetes curvos actúan de testigos y, vueltos hacia los escribas -también un clérigo y un laico-, levantan acta del acontecimiento. En la Estoria de España, se retrata una ceremonia regia solemne: el soberano exhibe manto con distintivos heráldicos y está acompañado por una comitiva cortesana que ocupa las filas inferiores de la imagen. Asimismo, las autoridades eclesiásticas asisten al acto (grupo superior izquierda, todos con bonetes negros curvos), entre ellos un obispo (el personaje más cercano al rey que porta mitra y capa pluvial). Pero la primacía absoluta de esta miniatura es la figura del propio soberano que exhibe la espada alzada en su mano derecha y con la izquierda entrega el códice al príncipe (viste lujoso manto y bonete bordado en oro) que, arrodillado, y acompañado por dos jóvenes infantes, recoge el presente.

Sin lugar a dudas, ambas imágenes retratan el ceremonial monárquico y se revisten de significado político. El propósito y sentido de las obras historiográficas: avalar a través de los hechos del pasado las aspiraciones políticas de Alfonso X como rey y como emperador, se proyectan en el lenguaje visual. Ambas ilustraciones son testimonios icónicos de legitimación y sucesión de poder. El códice, con la historia particular y la universal, agavilla las virtudes 
y méritos del rey en pro de su promoción personal y simboliza la transmisión linajista del poder, del reino y del modelo paterno de monarca. Así como la miniatura de la General Estoria, no solo artísticamente, sino también en cuanto al contenido, sigue la plantilla de las Cantigas, la que funciona como frontispicio de la Estoria de España es mucho más solemne y puede considerarse un acto oficial gubernamental e, incluso, legal; es la única imagen alfonsí en la que aparece con la espada -en clara alusión a la justicia- y con el códice, exhibiendo, por tanto, todos los atributos de su poder mayestático. Es esta, a mi juicio, la más nítida representación salomónica de Alfonso X y de su arquetipo político de realeza sapiencial: «la sabiduría como la virtud política por excelencia» $\mathrm{y}$ «la obtención y difusión de esta sabiduría se constituye en el sentido último del ejercicio del poder $[\ldots]\rangle^{18}$.

El códice de la Primera Partida (Londres, British Library, Add. ms. 20787) en su miniatura inaugural (f. 1r) ofrece una estampa muy similar a la de la Estoria de España: Alfonso X como legislador con la espada en la mano derecha y el libro de leyes en la izquierda. Este manuscrito se ha considerado tradicionalmente alfonsí, pero cada vez son más los estudiosos que defienden que se realizó con posterioridad a la muerte del rey y que presenta «particularidades codicológicas distintas al resto de los ejemplares, así como una serie de apreciaciones

\footnotetext{
${ }^{18}$ Manuel Alejandro Rodríguez de la Peña, «Rex excelsus qui scientiam diliget: la dimensión sapiencial de la Realeza alfonsí», art. cit., citas, respectivamente, pp. 122 y 112. El estudioso considera que: «en el corpus textual alfonsí encontramos la que quizá sea la teorización de la Realeza sapiencial más acabada de la Europa medieval. Una teorización sistemática realizada en textos de índole jurídica e histórica, así como en prólogos de traducciones científicas», p. 126. Y añade: «Este ideal sapiencial era fruto de una teología política que procedía primeramente del renacimiento carolingio y después del renacimiento del siglo XII, siendo la síntesis de dos tradiciones sapienciales diferentes: la grecorromana (platónica) y la judeocristiana (salomónica)», p. 126. Véanse también del mismo autor, «Imago sapientiae: los orígenes del ideal sapiencial medieval», en Medievalismo, 7 (1997), pp. 11-39; «Rex institutor scholarum: la dimensión sapiencial de la realeza en la cronística de León - Castilla y los orígenes de la Universidad de Palencia», en Hispania Sacra, LXII (2010), pp. 491-512 y «El paradigma de los reyes sabios en el De rebus Hispaniae de Rodrigo Jiménez de Rada», en Sevilla 1248. Congreso Internacional Conmemorativo del 750 aniversario de la conquista de Sevilla por Fernando III el Santo, rey de Castilla y León, coord. por M. González Giménez, Sevilla - Madrid, Ayuntamiento de Sevilla - Fundación Ramón Areces, 2000, pp. 757-765; recomiendo, asimismo, la consulta de H. Salvador Martínez, El humanismo medieval y Alfonso X el Sabio. Ensayo sobre los origenes del humanismo vernáculo, Madrid, Ediciones Polifemo, 2016. En cuanto a la aplicación de la imagen salomónica a Alfonso X, remito principalmente a Jean-Patrice Boudet, «El modelo del rey sabio en los siglos XIII y xIV: Salomón, Alfonso X y Carlos V», en Modelos culturales y normas sociales al final de la Edad Media, coord. por Patrick Boucheron y Francisco Ruiz Gómez, Cuenca, Casa de Velázquez - Ediciones Universidad de Castilla-La Mancha, 2009, pp. 53-73; Ana Domínguez Rodríguez, «El testamento de Alfonso X y la Catedral de Toledo», en Reales Sitios, 82 (1984), pp. 73-75 y «El Officium Salomonis de Carlos V en el Monasterio de El Escorial. Alfonso X y el planeta Sol. Absolutismo monárquico y hermetismo», en Reales Sitios, 83 (1985), pp. 11-28; Manuel Alejandro Rodríguez de la Peña, Los reyes sabios. Cultura y poder en la Antigüedad Tardia y la Alta Edad Media, Madrid, Actas, 2008, principalmente, pp. 105-138 y «Rex excelsus qui scientiam diliget: la dimensión sapiencial de la Realeza alfonsí», art. cit. Añádanse a estas referencias la bibliografía citada en la nota 5.
} 


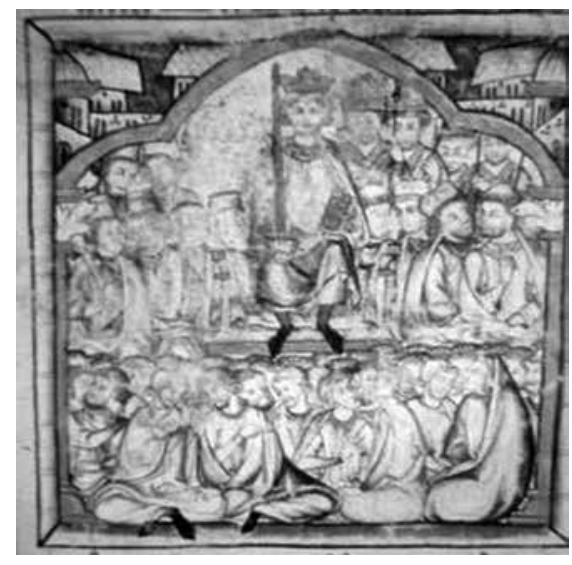

Primera Partida, Londres, British Library, Add. ms. 20787, f. 1r.

iconográficas y estilísticas que sugieren una cronología más tardía» ${ }^{19}$.

Si tenemos en cuenta que la miniatura de la Estoria de España es posterior a la realización del códice y que fue adicionada en folio aparte en el scriptorium regio, cabe pensar que quizá se sustituyó la original (realizada con el ejemplar, ca. 1274) -acaso con clara huella del objetivo imperial-, de acuerdo con las necesidades y pretensiones del momento. $\mathrm{Y}$ esto me induce a proponer la hipótesis de que la miniatura de la Estoria de España podría hacerse eco de la proclamación oficial de Sancho como heredero al trono -Cortes de Segovia de abril de 1278-. No se olvide que el conflicto sucesorio debilitó enormemente el poder de Alfonso X y lo enfrentó con buena parte del reino; reconocer finalmente a su segundogénito como futuro rey calmaba el malestar de un importante sector de la nobleza y de los concejos de Castilla y, en cierto modo, restituía su autoridad regia. La miniatura de Alfonso X exhibiendo su imago maiestatis y magnificando su potestas al designar al sucesor de la corona -invistiéndose como el nuevo Salomón- evidencian un claro ejercicio visual de propaganda política y fortalecimiento del poder.

\section{Las Cantigas: imágenes del proceso de creación literaria}

Hacia 1280 el scriptorium se vuelca con los códices de las Cantigas, uno de los proyectos, sin duda, más relevantes de la producción alfonsí, gestado al inicio de su reinado y que fue ampliándose en diferentes fases hasta alcanzar

${ }^{19}$ El códice de la Primera Partida - con un total de 27 ilustraciones, siete de ellas en el interior de capitales- presenta cuatro miniaturas de Alfonso X: prólogo, imagen inaugural, f. 1r; prólogo, letra capital A, f. 1r; comienzo primer libro, f. 1v; inicio del título primero en una capital A, f. 1v. Laura Fernández Fernández, «Los manuscritos de las Cantigas de Santa María: definición material de un proyecto regio», art. cit. cita p. 203, n. 50; véase también José Sánchez-Arcilla, «La "teoría de la ley” en la obra legislativa de Alfonso X el Sabio», en Alcanate, VI (2008-2009), pp. 81-124. Por su parte, Ana Domínguez Rodríguez, «Retratos de Alfonso X el Sabio en la Primera Partida (British Library, Add. ms. 20.787). Iconografía y cronología», en Alcanate, VI (2008-2009), pp. 239-251, considera este ejemplar obra del scriptorium alfonsí: «La iconografía de estos cuatro retratos del rey Sabio es muy coherente con las pretensiones políticas y jurídicas del rey Sabio anteriores al año 1272 (el ms. Add. 20787 está fechado entre los años 1256 y 1265)», cita pp. 249-250. 
su definición material última en cuatro manuscritos regios ${ }^{20}$. De acuerdo con las conclusiones de Laura Fernández Fernández, el Códice de Toledo (BNE, ms. 10069), realizado entre 1270 y 1280, sería una copia muy próxima al ejemplar original. Y respecto a los tres testimonios iluminados propone la siguiente cronología: el Códice Rico (BE, T.I.1) se iniciaría hacia 1280 y en torno a 1282, el Códice de Florencia (Biblioteca Nazionale Centrale de Florencia, ms. B.R.20) -que quedaría incompleto debido al óbito del monarca-; en las mismas fechas también se comenzaría el Códice de los Músicos (BE, ms. B.I.2); por tanto, «en los últimos años del reinado, entre 1282 y 1284, se llevarían a cabo ambos manuscritos, al mismo tiempo que se finalizaban los pormenores de T [Códice Rico]». Mientras que los Códices de las Historias «fueron concebidos como libros de uso personal del monarca y los miembros de Palacio, por lo tanto deben ser entendidos en su dimensión plenamente cortesana, y como parte del patrimonio librario de la corona», el Códice de los Músicos «desde el origen de su planteamiento estuviera vinculado al proyecto de la Capilla Real hispalense [...] y las Cantigas fueran cantadas en la Capilla Real durante las fiestas de Santa María» ${ }^{21}$.

${ }^{20}$ Sobre la bibliografía de las Cantigas de Santa Maria remito a Joseph T. Snow, The Poetry of Alfonso X. An Annotated Critical Bibliography (1278-2010), London, Tamesis Books, 2012 y a la base de datos The Oxford Cantigas de Santa Maria Database. [En línea]. Enlace: <http://csm.mml.ox.ac.uk/> [Consulta: 13/02/2016].

${ }^{21}$ Laura Fernández Fernández, «“Este livro, com’ achei, fez á onr’e á loor da Virgen Santa Maria”. E1 proyecto de las Cantigas de Santa María en el marco del escritorio regio. Estado de la cuestión y nuevas reflexiones», en Alfonso X el Sabio, Las Cantigas de Santa María. Códice Rico, Ms. T-I-1 Real Biblioteca del Monasterio de San Lorenzo de El Escorial, coord. por Laura Fernández Fernández y Juan Carlos Ruiz Souza, 2 vols., Madrid, Testimonio Editorial-Patrimonio Nacional, 2011, I, pp. 45-78, citas respectivamente p. 78 y pp. 51-53 y «Los manuscritos de las Cantigas de Santa María: definición material de un proyecto regio», art. cit. Es probable, a juicio de la estudiosa, que la Compilación tabular del Arsenal quedase sin terminar al ser relegada su finalización por los códices de las Cantigas, ibídem, p. 116, n. 88. Véanse también John E. Keller y Richard P. Kinkade, Iconography in Medieval Spanish Literature, Kentucky, University Press of Kentucky, 1984, pp. 6-40; Inés Fernández Ordóñez, «Las Cantigas de Santa María en el marco de las producciones alfonsíes: semejanzas y diferencias», en Alfonso X el Sabio, ob. cit., coord. por L. Fernández Fernández y J. C. Ruiz Souza, 2011, I, pp. 6-15; Elvira Fidalgo, As Cantigas de Santa María, Vigo, Edicións Xerais de Galicia, 2002 y «La gestación de las Cantigas de Santa María en el contexto de la escuela poética gallego-portuguesa», en Alcanate, VIII (2012-2013), pp. 17-42; Rocío Sánchez Ameijeiras, «Imaxes e teoría da imaxe nas Cantigas de Santa María», en Elvira Fidalgo, As Cantigas de Santa María, Vigo, Edicións Xerais de Galicia, 2002, pp. 245-301 y «Del Salterio al Marial: sobre las 'fuentes' de las imágenes de los Códices de las Historias de las Cantigas de Santa María», art. cit. Asimismo, consúltese la bibliografía citada en nota 7. Sobre el peregrinaje y fortuna de los manuscritos de las Cantigas: Laura Fernández Fernández, «Cantigas de Santa María: fortuna de sus manuscritos», en Alcanate, VI (2008-2009), pp. 323-348 e «Historia florentina del Códice de Cantigas de Santa María, Ms. B.R.20 de la Biblioteca Palatina a la Nazionale Centrale», en Reales Sitios, 164 (2005), pp. 18-29 y Rocío Sánchez Ameijeiras, «La fortuna sevillana del códice florentino de las Cantigas: tumbas, textos e imágenes», en Quintana, 1 (2002), pp. 257-273. 
Las miniaturas de los códices de las Cantigas han sido profusamente analizadas y es pleno el acuerdo de que la aparición sistemática de Alfonso X puede catalogarse en tres funciones principales: la de trovador-autor, la de trovador-narrador y la de trovador-actor ${ }^{22}$. Por mi parte, en esta ocasión, únicamente atenderé a las imágenes liminares.

En el Códice Rico (BE, T.I.1), además de aumentar el número de cantigas a 200 -aunque solo se llega hasta la 195-, se incorporó la narración icónica de los poemas en exquisitas miniaturas y su notación musical, lo que condicionó la impaginación del manuscrito, ya que lo que se pretendía era que con el libro abierto se pudiese contemplar a un tiempo el texto, con su melodía correspondiente (verso del folio), y el aparato visual (recto del folio siguiente $)^{23}$. En clara correspondencia con este esquema, la cantiga-prólogo (f. $4 \mathrm{v}$ ) conforma un bifolio con la intitulación y primera cantiga de loor (f. 5r) y sus respectivas ilustraciones.

\footnotetext{
${ }^{22}$ Remito principalmente a María Victoria Chizo Picaza, Composición pictórica en el Códice Rico de las Cantigas de Santa María, Madrid, Universidad Complutense, 1987; «La visión de "sones" y "trobas". Composición pictórica y estilo en la miniatura del Códice Rico», en Alfonso X el Sabio, ob. cit., coord. por L. Fernández Fernández y J. C. Ruiz Souza, 2011, I, pp. 411-443 y «Composición, estilo y texto en la miniatura del Códice Rico de las CSM», en Alcanate, VIII (2012-2013), pp. 161-189; Joaquín Yarza Luaces, «Reflexiones sobre la iluminación de las Cantigas», en Metropolis totius Hispaniae. Catálogo de la exposición del 750 aniversario de la incorporación de Castilla a la corona castellana, ed. de A. J. Morales, Sevilla, Real Alcázar de Sevilla, 1988, pp. 163-179; Ana Domínguez Rodríguez, «Imágenes de un rey trovador de Santa María (Alfonso X en las Cantigas), en Il Medio Oriente e l'Occidente nell'arte del XIII secolo. Atti del XXIV Congreso Internazionale di Storia dell'Arte (Bologna, settembre 1979), ed. de Hans Belting, Bologna, Cooperativa Libraria Universitaria Editrice, 1982, pp. 229-239; Laura Fernández Fernández, «Imagen e intención. La representación de Santiago Apóstol en los manuscritos de las Cantigas de Santa María», en Anales de la Historia del Arte, 18 (2008), pp. 73-94; Rafael Cómez Ramos, «El retrato de Alfonso X, el Sabio en la primera Cantiga de Santa María», en Studies on the Cantigas de Santa Maria: Art, Music, and Poetry. Proceedings of the International Symposium on the Cantigas de Santa Maria of Alfonso X, el Sabio (1221-1284) in Commemoration of Its 700th Anniversary Year-1981 (New York, November 19-21), ed. de Israel J. Katz y John E. Keller, Madison, Hispanic Seminary of Medieval Studies, 1987, pp. 35-52. George D. Greenia, «A New Manuscript Illuminated in the Alphonsine Scriptorium», en Bulletin of the Cantigueiros de Santa Maria, 2 (1988-1989), pp. 31-42, relaciona estilísticamente las miniaturas del Códice Rico de las Cantigas con el manuscrito 47-15 de la Catedral de Toledo.

${ }^{23}$ Laura Fernández Fernández y Elisa Ruiz García, «Quasi liber et pictura. Estudio codicológico del Ms. T-I-1, RBME», en Alfonso X el Sabio, ob. cit., coord. por L. Fernández Fernández y J. C. Ruiz Souza, 2011, I, pp. 109-143; Elisa Ruiz García, «Escribir para el rey. Estudio paleográfico del ms. T-I-1 de la Real Biblioteca de El Escorial», en ibídem, pp. 44-84 y «Modernidad y pulcritud en la composición material de los códices ricos de las Cantigas», en Alcanate, VII (2012-2013), pp. 119-160.
} 

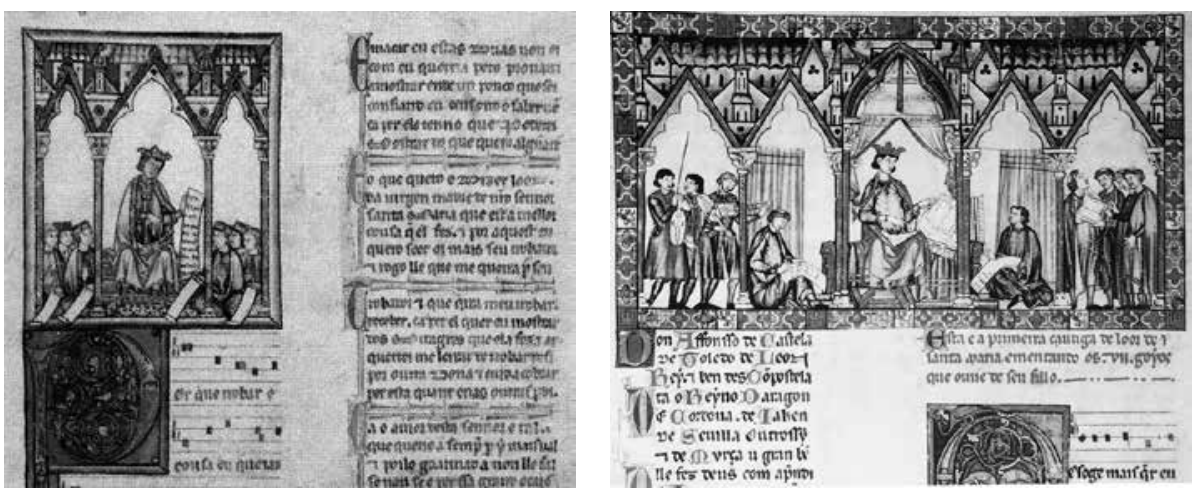

Códice Rico, BE, ms. T.I.1, ff. 4v y 5 r.

La imagen primera, siguiendo el patrón ensayado en los textos científicos, ilustra el contenido del proemio que, a todas luces, puede considerarse la cantiga programática del cancionero mariano. Alfonso X detalla la poética, la técnica y el talento del arte de trovar, que va a poner en práctica para componer sus cantares en loor de la Virgen. La labor literaria del trovador y, como tal, la petición poética cortés de vasallaje y galardón espiritual son el puntal retórico del marial alfonsí. He aquí que la miniatura inaugural: el rey con un rótulo lee a sus colaboradores el íncipit de la obra «Porque trobar é cousa en que jaz entendimiento, por én quen o faz ao d'aver de», sienta las bases del proyecto y marca el inicio del mismo -los personajes que flanquean al monarca sostienen con una mano rótulos en blanco y únicamente lo escuchan-. Así pues, se establece una relación directa entre la imagen, el texto del prólogo y la acción literaria de creación. El rey-trovador de la primera ilustración (f. $4 \mathrm{v}$ ) se corona como rey-autor en la segunda (f. 5r). Esta miniatura, que ocupa todo el ancho de la caja de escritura, a mi juicio, comprende dos momentos: por un lado, la fase de composición y/o revisión intelectual y musical, representada por los dos colaboradores que están más cerca del monarca, el de la derecha es el encargado del texto de las cantigas -en concreto se puede leer el segundo verso «pola sennor onrada» de la primera cantiga de loor-; y el de la izquierda está repasando los neumas del primer verso de dicha composición «Des oge máis que' eu trobar» en un pentagrama ${ }^{24}$. Y, en segundo lugar, si

${ }^{24}$ El personaje de la derecha «en su mano derecha luce el cálamo alzado en gesto de escribir, así como el tintero en su mano izquierda; asimismo podemos apreciar junto a sus piernas el soporte a modo de carpeta de piel roja, el mismo objeto escritutario que aparece en todas las representaciones de los copistas de las imágenes de apertura de los códices alfonsíes. Sin embargo, su compañero está trabajando [...] la melodía de la cantiga. Esta sutil diferencia entre ambos personajes parece concluir que el trabajo de notación musical se llevaría a cabo una vez escrito el poema, tal y como aparece en la imagen. [...] dicho personaje no porta ninguna herramienta escrituraria, ni se encuentra en actitud de trazar ningún signo sobre el so- 
fijamos la atención en los dos grupos de sujetos situados en los últimos arcos, cantores y músicos, estamos ya en la fase de interpretación de los cantares y, por tanto, lo que se representa es la consumación del proyecto y del trovar.

Esta escena prácticamente se reproduce en el Códice de los Músicos $(\mathrm{BE}$, ms. B.I.2, f. 29r), el único que se completó con las 400 cantigas, y "posiblemente motivado por la lentitud con la que se avanzaba en F [Códice de Florencia]. Este hecho explicaría que fuese realizado con cierta premura e introduciendo cambios significativos en su estructura $\rangle^{25}$. La miniatura inaugural tomó como base la del Códice Rico -aunque el equipo de iluminadores era distinto- $\mathrm{y}$, además, al final de la primera columna del folio $28 \mathrm{v}$ se observa un espacio en blanco destinado, con toda probabilidad, a emular la imagen que principia la columna del folio $4 \mathrm{v}$ del Códice Rico.

El centro privilegiado de estas miniaturas lo ostenta el rey con el libro, siguiendo el modelo ya delineado en las compilaciones científicas -como hemos visto en páginas anteriores-. El volumen es el resultado del proceso de composición intelectual y material y, al tiempo, es la base de la ejecución musical y vocal.

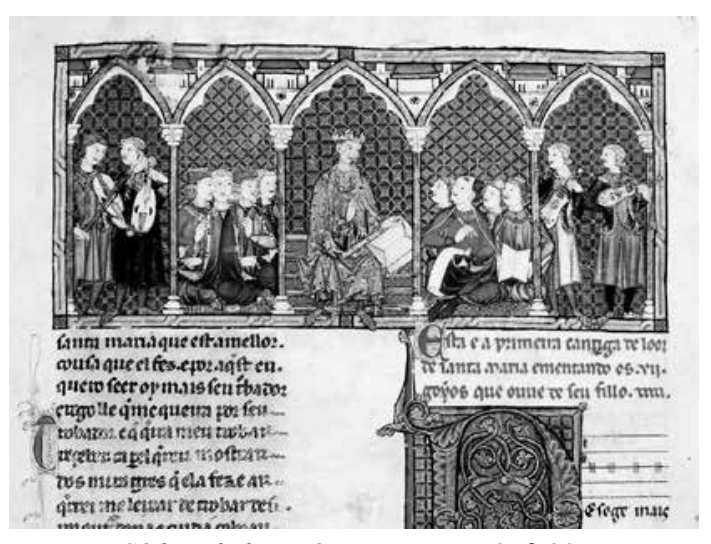

Códice de los Músicos, BE, B.I.2, f. 29r.

Especial atención requiere la secuencia que se establece en las imágenes liminares de los Códices de las Historias: si bien el Códice de Florencia (Biblioteca Nazionale Centrale de Florencia, ms. B.R.20) se gesta como la continuación y ampliación con 200 nuevas cantigas del Códice Rico en un segundo volumen; de igual modo, hay que considerar el vínculo y progresión que se observa entre las miniaturas de inicio de ambos ejemplares.

porte escritorio, aunque tradicionalmente lo hemos calificado de copista. Más bien parece señalar, o guiar su mirada sobre el pentagrama con los dedos de su mano derecha», Laura Fernández Fernández, «Los manuscritos de las Cantigas de Santa María: definición material de un proyecto regio», art. cit., pp. 95-96.

${ }^{25}$ Véase ibidem, principalmente pp. 105-112 y Martha E. Shaffer, «The 'Evolution? of the Cantigas de Santa María: The Relationships between MSS T, F, and E», en Cobras e son. Papers on the Text, Music and Manuscripts of the Cantigas de Santa Maria, ed. de Stephen Parkinson, Oxford, Legenda, 2000, pp. 186-213. Un completo análisis del Códice de Florencia y de sus miniaturas en Amparo García Cuadrado, Las Cantigas: el Códice de Florencia, Murcia, Universidad de Murcia, 1993. 


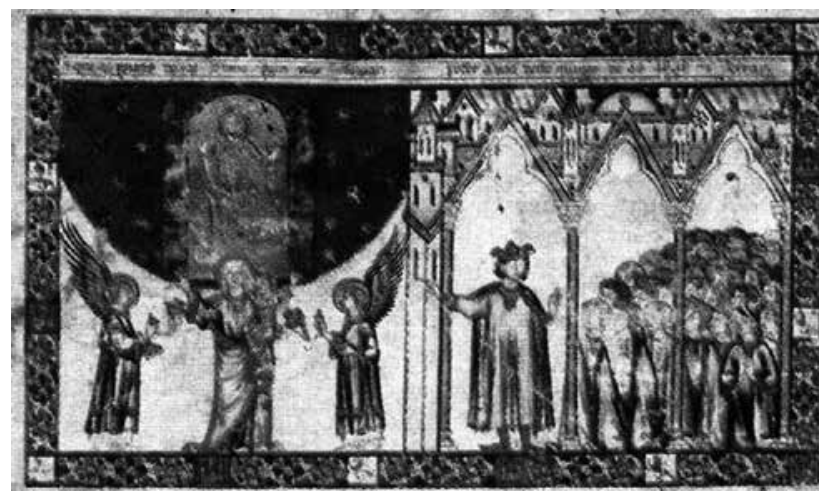

Códice de Florencia, Biblioteca Nazionale Centrale de Florencia, ms. B.R.20, f. 2r [IIIr].

Esta viñeta reproduce la primera parte del estribillo de la cantiga inicial: «A que as portas do ceo $\mid$ abriu pera nos salvar, | poder á nas deste mundo $\mid$ de as abrir e serrar» ${ }^{26}$. El Códice Rico concluía con una cantiga de loor y el de Florencia, siguiendo el esquema compositivo del proyecto, se inicia con la narración de un milagro. La ilustración, al igual que en el primer volumen, ocupa todo el ancho de la caja de escritura, destacando así su relevancia. Y, en total simetría con la miniatura del Códice Rico, también se aprecian dos estadios: por una parte, Alfonso X, como trovador-narrador (mitad derecha), recita el milagro marial a un grupo coral que escucha con suma atención y devoción y, por otra (mitad izquierda), la estampa de la Virgen protagonizando el contenido del refrán de la cantiga: «A que as portas do ceo | abriu pera nos salvar» y consumando su función de mediadora entre los hombres y su hijo, al tiempo que se subraya su entidad divina, simbolizada por su ascenso a los cielos custodiada por dos ángeles. Es, asimismo, el papel del rey como intercesor entre la Virgen y sus súbditos lo que se enfatiza en esta miniatura, en un claro proceso de sacralización de la figura de Alfonso $\mathrm{X}$-que concretado en el origen divino de la monarquía se convirtió en una de las imágenes teológicas de mayor fortuna para la monarquía medieval-.

En los Códices de las Historias, las miniaturas liminares estampan «el trovar» de Alfonso X como un completo proceso que abarca la creación intelectual y física del cancionero mariano (Códice Rico) y la devota narración pía de los loores y milagros de la Virgen (Códice de Florencia) ${ }^{27}$. El soberano

\footnotetext{
${ }^{26}$ En el Códice de los Músicos (BE, ms. I.b.2) es la cantiga número 246, ff. 224r-225r. El epígrafe reza: «Dũa bõa moller que ia cada sabado a hũa eigreja que chaman Santa Maria das Martires, e obridóxe-lle, e depois foi alá de noite, e abriron-xe-lle as portas da eigreja». Para el análisis de esta imagen véanse, Ana Domínguez Rodríguez, «Imágenes de un rey trovador de Santa María (Alfonso X en Las Cantigas)», art. cit.; Teresa Lopes Pereira, «O culto de Nossa Senhora dos Mártires em Alcácer do Sal, a Senhora da Cinta e as Cantigas de Santa María», en Medievalista, 6 (2009), pp. 1-23 y Martha E. Shaffer, "The 'Evolution? of the Cantigas de Santa Maria: The Relationships between MSS T, F, and E», art. cit. especialmente, pp. 202-203.

${ }^{27}$ Sobre la espiritualidad en las miniaturas de las Cantigas, Ana Domínguez Rodríguez, «Poder, ciencia y religiosidad en la miniatura de Alfonso X el Sabio. Una aproximación», en Fragmentos, 2 (1984),
} 
perpetuará con sus cantares y remedará con su actividad de trovador la labor mediadora de la Virgen y, en consonancia, su imagen teológico-política de representante en la tierra del poder divino y de monarca protegido por la divinidad -recuérdese la cantiga 209 en la que Alfonso X, enfermo en Vitoria en 1276, es sanado por el contacto directo con su cancionero, adquiriendo el códice estatuto taumatúrgico-. Pero, llegados a este punto, lo que conviene subrayar es que con los códices de las Cantigas se consolida la imagen del rey con el libro como arquetipo de la semblanza pictórica de Alfonso X e intitulación de su saber. Estas ilustraciones de las Cantigas, más allá del efecto retórico metaliterario y especular, estampan simbólicamente el amplio elenco de atributos y funciones que conforman el perfil autoral alfonsí.

\section{Libro de los juegos: «queremos agora aquí contar» $y$ «fablar»}

El Libro del ajedrez, dados y tablas, terminado en Sevilla en 1283, es el último eslabón de la producción alfonsí2 ${ }^{28}$. Las miniaturas de inicio de los distintos juegos -Prólogo y Libro del ajedrez (f. 1r), Libro de los dados (f. 65r) y Libro de las tablas (f. 72r)- ocupan el tercio superior de la caja de escritura y continúan el arquetipo de representación de Alfonso X consolidado en las Cantigas: el rey en el proceso de creación de su obra.

pp. 33-47; «Iconografía evangélica en Las Cantigas de Santa María», en Reales Sitios, 80 (1984), pp. 37-44; «Compassio y co-redemptio en Las Cantigas de Santa María. Crucifixión y Juicio Final», en Archivo Español de Arte, 281 (1988), pp. 17-35; «La Virgen, rama y raíz. De nuevo con el árbol de Jesé en las Cantigas de Santa María», en Scriptorium alfonsi, de los libros de astrología a las Cantigas, coord. por A. Domínguez Rodríguez y J. Montoya Martínez, Madrid, Universidad Complutense, 1999, pp. 175-214 y «San Bernardo y la religiosidad cisterciense en las Cantigas de Santa María», en Literatura y cristiandad. Homenaje al profesor Jesús Montoya Martínez (con motivo de su jubilación). Estudios sobre hagiografia, mariología, épica y retórica, ed. de Manuel Alonso García, Granada, Universidad de Granada, 2001, pp. 289-317; María Victoria Chico Picaza, «Hagiografía en las Cantigas de Santa María: bizantinismos y otros criterios de selección», en Anales de Historia del Arte, 9 (1999), pp. 33-54 y Alejandro García Avilés, «Imágenes "vivientes”: idolatría y herejía en las Cantigas de Alfonso X el Sabio», en Goya, 321 (2007), pp. 324-342.

${ }^{28}$ Sobre las miniaturas del Libro del ajedrez, dados y tablas véanse principalmente, Ana Domínguez Rodríguez, «El Libro de los Juegos y la miniatura alfonsí», en Alfonso X el Sabio, Libros del ajedrez, Dados y Tablas, ed. facsímil, Madrid - Valencia, Patrimonio Nacional - Vicent García, 1987, volumen complementario, pp. 30-123 y «Retratos de Alfonso X en el Libro de los Juegos de Ajedrez, Dados y Tablas», en Alcanate, VII (2010-2011), pp. 147-161; J. T. Wollesen, «Sub specie ludi... Text and Images in Alfonso El Sabio's Libro de Acedrex, Dados e Tablas», en Zeitschrift für Kunstgeschichte, 55 (1990), pp. 277-308; Heather Bamford, «El ajedrez, juego de espacio, personajes y alteridad: nuevas ideas respecto a las imágenes del Libro de ajedrez alfonsí», en Emblemata, 15 (2009), pp. 15-28; Pedro L. Lavado Paradinas, «Imágenes del juego de ajedrez», en Cuadernos de Arte e Iconografia. Actas de los II Coloquios de Iconografia, IV:7 (1991), pp. 94-102; S. Musser Golladay, Los Libros de acedrex, dados e tablas: Historical, Artistic and Metaphysical Dimensions of Alfonso X's Book of Games, Tesis Doctoral, Tucson, Universidad de Arizona, 2007 y Braulio Vázquez Campos, «El Rey en jaque: Alfonso X y el ajedrez», en Alcanate, VII (2010-2011), pp. 293-328. 


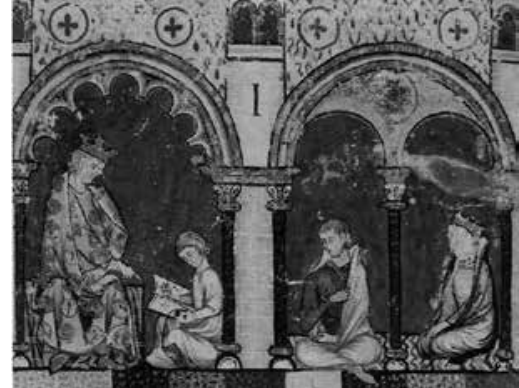

Libro del ajedrez, dados y tablas, BE, ms. T.I.6, prólogo general y prólogo Libro del ajedrez, f. 1r.

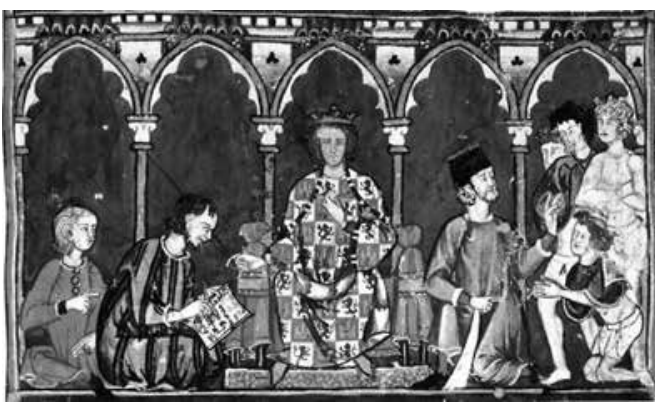

Libro del ajedrez, dados y tablas, BE, ms.

T.I.6, prólogo Libro de los dados, f. 65r.

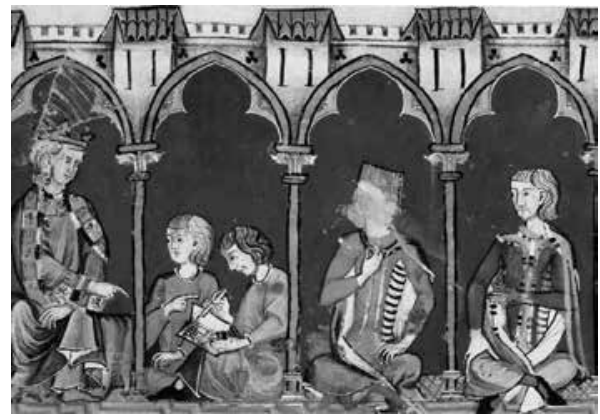

Libro del ajedrez, dados y tablas,

BE, ms. T.I.6, prólogo Libro de las tablas, f. 72r.

No obstante, hay que advertir que estamos ante una variación del modelo. Alfonso X aparece en las tres ilustraciones en actitud de dictar al escriba, que con la pluma en la mano copia las palabras de su interlocutor; bien puede pensarse que se trata de los prefacios -muy escuetos en los dos últimos libros-en los que la presencia del rey queda manifiesta por la primera persona del plu$\mathrm{ral}^{29}$. Nótese que estas imágenes son las únicas en las que el rey no contempla o porta el ejemplar del libro -como resultado final de un proceso concluido-, por tanto, no sería aventurado argüir que estas miniaturas concretan la fase de composición y denotan una acción en progreso que se corresponde con las propias palabras de Alfonso X en los proemios: «fabla en este libro primeramientre d'él [ajedrez] (f. 2v), «queremos agora aquí contar de los juegos de los dados» (f. 65r) y «queremos agora aquí fablar de las tablas» (f. 72r); un «agora» que fusiona el presente textual e icónico.

${ }^{29}$ Para otras posibles imágenes de Alfonso X en el Libro del ajedrez, dados y tablas, remito a Ana Domínguez Rodríguez, «Retratos de Alfonso X en el Libro de los Juegos de Ajedrez, Dados y Tablas», art. cit., pp. 155-161 y «El Officium Salomonis de Carlos V en el Monasterio de El Escorial: Alfonso X y el planeta Sol. Absolutismo monárquico y hermetismo», art. cit., pp. 11-28. 
En el prólogo general (ff. 1r-2r), Alfonso X justifica el porqué del libro: «Nós, don Alfonso, [...] mandamos fazer este libro en que fablamos en la manera d'aquellos juegos que se fazen más apuestos, assí como acedrez y dados y tablas» (f. 1v). Y, a continuación, «las razones de los sabios antiguos» y el relato del origen de estos pasatiempos serán la base de la legitimación sapiencial de la materia lúdica (ff. 1r-2r):

Segunt cuenta en las istorias antiguas en India, la Mayor, ovo un rey que amava mucho los sabios y teníelos siempre consigo [...]. Y d'estos avié ý tres que tenién señas razones. [...] Y desque ovieron dichas sus razones [...] mandoles el rey que $\cdot 1$ aduxiesse ende cada uno muestra de prueva d'aquello que dizién y dioles plazo [...]. El que tenié razón del seso, troxo el acedrex con sus juegos, mostrando que el que mayor seso oviesse y estudiesse aperçebudo podrié vencer al otro. Y el segundo, que tenié la razón de la ventura, troxo los dados, mostrando que no valié nada el seso, sino la ventura [...]. El tercero, que dizié que era mejor tomar de lo uno y de lo ál, troxo el tablero con sus tablas contadas y puestas en sus casas ordenadamientre y con sus dados que las moviessen para jugar (ff. $1 \mathrm{v}-2 \mathrm{r}$ ).

Ilustrando el prefacio se incorporan tres miniaturas que, como puede observarse seguidamente, además de los paralelismos visuales, enlazan la labor del rey indio y sus sabios consejeros (imagen tercera) con la de Alfonso X y sus amanuenses (imagen primera) y el vínculo de unión es la estampa del scriptorium (imagen segunda). En las imágenes del Libro del ajedrez, dados y tablas, la simbología del libro es subsumida por el emblema de la labor de traducción, creación, y manufactura de todos los proyectos librarios regios: el taller alfonsí.

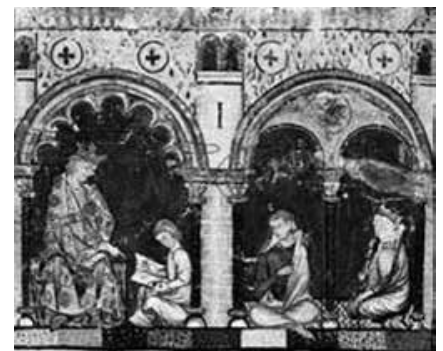

Libro del ajedrez, dados y tablas, BE, ms. T.I.6, f. $1 \mathrm{r}$.

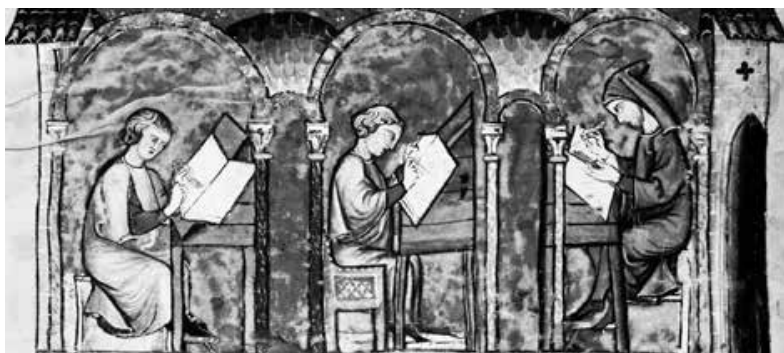

Libro del ajedrez, dados y tablas, BE, ms. T.I.6, f. 1v. 


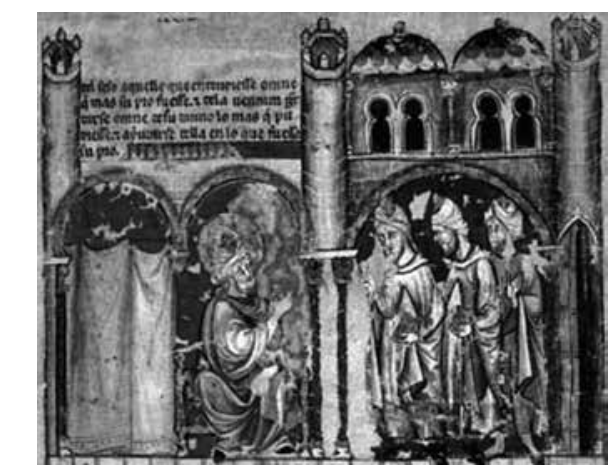

Libro del ajedrez, dados y tablas, BE, ms. T.I.6, f. 2r.

\section{Modelo iconográfico de la realeza sapiencial de Alfonso $X$}

El motivo icónico privilegiado en las imágenes liminares de representación personal de Alfonso X es el rey con el libro, que -tal y como se ha expuesto en las páginas que anteceden- presenta distintas variantes relacionadas tanto con el género literario y visual, como con la amplia gama de atribuciones que conforman el concepto de autoría alfonsí. En las compilaciones científicas, el monarca se ubica en las capitales historiadas que principian los prólogos, es así como la presencia conceptual del rey se refleja también con su propia figuración. En estas ilustraciones proemiales, los colaboradores son los que muestran el ejemplar abierto al monarca, como resultado y plasmación visual de su patronazgo traductor y compilador. En las miniaturas de las Cantigas, la imagen del soberano adquiere notable protagonismo, tanto por el tamaño y disposición de las pinturas, como artísticamente por la mayor riqueza ornamental. En los códices del marial asistimos a la estampa más notoria de la intervención de Alfonso X en el proceso de composición intelectual y material de la obra. El rey trovador armoniza la función de autor y la devoción religiosa, el cancionero adquiere calado sagrado y el rey contemplando el libro abierto personifica icónicamente el concepto teológico-político de representante, elegido y protegido por la divinidad. Estamos ante la semblanza pictórica por excelencia de Alfonso X como rex sapiens, rex scribens y rex pius. El motivo iconográfico se altera en las Estorias: el monarca exhibe el libro cerrado y entra en escena el heredero, son ceremoniales monárquicos de sucesión de poder. El volumen, con la historia universal y particular, proyecta una nítida aureola propagandista de defensa de la ideología monárquica y de promoción del linaje alfonsí. En estas pinturas se enfatiza el alcance político y el códice se revela como un regalia principal -en la Estoria de España, en 
una mano porta el libro y en la otra, la espada-. El último eslabón de la producción literaria de Alfonso X, el Libro del ajedrez, dados y tablas, continúa el arquetipo precisado en las Cantigas: el rey con sus copistas y colaboradores dictando o supervisando su trabajo; sin embargo, es este el único códice regio en el que el rey es figurado sin el libro; en su lugar la imagen del scriptorium se alza como divisa de la labor literaria de Alfonso X.

Las miniaturas de apertura de los códices alfonsíes, amén de imprimir el sello de exclusividad y calidad del scriptorium regio y enaltecer la valía de la obra al estar vinculada al rey, consolidan el modelo iconográfico de la realeza sapiencial castellana: el soberano en la corte, sentado en su escaño y luciendo sus atributos mayestáticos, se convierte en la imagen ideal del poder monárquico. La superioridad hierática y autoridad es representada por el monarca entronizado, la solemnidad y supremacía de su presencia se cifra en la suntuosidad de sus atavíos y la corona simboliza la transmisión del poderío regio, su dimensión sacra y la acción gubernativa. Alfonso $\mathrm{X}$ individualiza y personifica esta formulación icónica prototípica e ideal de la majestad regia y de su potestas, encumbrando el saber, simbolizado por el libro, a la categoría de regalia. El códice es la plasmación de la potestad, erudición, intereses, pensamiento, obras y aspiraciones del soberano y el resultado del saber, de la voluntad y del poder del rey. La memoria del saber y del poder se concreta en el libro como legado de la historia, ciencia, gobierno, aficiones y creencias alfonsíes y, a través de él, perdurará en la historia como vestigio de su fama intelectual.

La dimensión política de la institución monárquica se supedita al desarrollo y difusión del conocimiento y sabiduría para implementar una doctrina cortesana propagandista cifrada en la figura de Alfonso X, que iconográficamente es miniado con la corona y el códice, atributos que estampan la semblanza alfonsí del ideal sapiencial intelectual y político.

Recibido: $1 / 03 / 2016$

Aceptado: 6/06/2016 


\section{$\cos$}

SemblanZa iconográfica de la REALEZa SAPIENCIAL DE Alfonso X:

LAS MINIATURAS LIMINARES DE LOS CÓDICES REGIOS

RESUMEN: La producción libraria de Alfonso X testimonia la simbiosis perfecta entre las funciones de gobierno y la labor intelectual y sistematiza su ideario político y cultural, no solo en texto, sino también en imagen. A partir de las miniaturas liminares de los códices regios, se evidencia que el motivo icónico privilegiado en la representación personal de Alfonso X es el rey con el libro: se analizan las distintas variantes de este modelo iconográfico que estampa la amplia gama de atribuciones que conforman el concepto de autoría alfonsí y consolida el modelo de la realeza sapiencial castellana.

Palabras clave: Alfonso X. Códices regios. Miniaturas. Motivo icónico. Realeza sapiencial.

The IConographic Representation of Alfonso X's Wise KingshiP: the Preliminary Miniatures in the Castilian Royal Manuscripts

ABSTRACT: The written legacy of Alfonso X not only represents the perfect symbiosis between power and wisdom, but also expresses the Castilian monarch's political and cultural beliefs through text and symbolic imagery. Departing from a close study of the preliminary miniatures in the royal manuscripts, this article reveals that the most prevalent motif representing Alfonso $\mathrm{X}$ is that of the king holding a book. Furthermore, the article delves into the different variants of this iconographic pattern which best illustrates the wide range of manifestations that shape the concept of Alphonsine authorship and reinforce the Castilian ideal of wise kingship.

KeYwords: Alfonso X. Royal manuscripts. Illuminations. Iconographic motifs. Wise kingship. 